\title{
Marketing Strategy Sharia Financial Institutions to Promote Sharia Fintech and Micro and Small Enterprises (MSES)
}

\author{
Vinnoya Apcaresta Alika ${ }^{1}$, Sugeng Santoso ${ }^{2}$, Siti Nurmaliki $^{3}$, Nur Anisa $^{4}$ \\ \{55119110020@student.mercubuana.ac.id ${ }^{1}$,sugeng.santoso@mercubuana.ac.id², \\ 355119110156@student.mercubuana.ac.id ${ }^{3}, 455119110009 @$ student.mercubuana.ac.id $\left.{ }^{4}\right\}$
}

Universitas Mercu Buana, Jakarta, Indonesia ${ }^{12345}$

\begin{abstract}
Currently, Indonesia's economic financing instruments that comply with sharia principles continue to increase, but further acceleration is needed to encourage significant growth. Because when viewed from the very broad market share of Islamic financing, there is an indication of a gap between the needs of sharia business and Islamic financing sources. The purpose of this research is to provide solutions in the form of convenience that can bridge sharia businesses by utilizing sources of financing through digital media in the form of sharia fintech. From the results of the analysis, the development of Fintech carried out by financial institutions, be it banking, savings and loan cooperatives and other financial institutions, can increase financial literacy and financial inclusion in MSEs. The results of this study were obtained from distributing questionnaires to 40 MSEs that became primary data. This questionnaire consists of 30 questions that are described based on several variables to be studied, including: the relationship between the level of FINTECH (X1), Quality System (X2), Features of service (X3), and Wishes to use SHARIA FINTECH (X4) on UMK Performance (Y). From the results of the Analysis of Correlation Variables and Reliability Test Results of the variables that (X1), (X2), (X3), (X4) have a significant effect on (Y). Based on the OJK list, the latest data shows that 7 Fintech companies labeled Sharia have sold Islamic loans. Judging from the needs of MSEs players, the closest Fintech is Laku Habis. Laku Habis develops productive and investment businesses in improving the quality of activities of MSEs by encouraging saving activities and supporting financing.
\end{abstract}

Keywords: Fintech, MSES, Syariah, Laku Habis

\section{Introduction}

Financial institutions are business entities or institutions in the field of financial services that move by collecting funds from the community and channel it in the form of loans/credits that aim to profit in the form of interest or margin. Financial institutions are divided into two types, namely, banking and nonbanking. The activities of collecting and channeling funds by financial institutions that are often utilized by the community are the facilities of storage of funds (savings) and lending (credit). In the digital world, innovations are emerging in the financial sphere of financial institutions, both encouraging the growth of the economy in a better direction. It is currently the most impactful financial sector of technological developments. Gradually this development happened so rapidly changed the financial industry into the digital era. The combination of technology and finance is often interpreted 
as financial technology (Fintech). With the advent of Fintech is expected to improve the welfare of society. The digital development provides a stimulus that needs to be responded by Sharia economics. One way of Sharia economics in order to encourage digitization is to drive transactions with sharia principles through internet media. The global digital Economy market in 2014 reaches USD 1.9 trillion or about $\mathrm{Rp} 27,550$ trillion. The value is calculated from e-commerce transactions and digital advertising expenditure. This market is expected to grow 15 per cent to the year 2020 .

Financial Technology (Fintech) is growing rapidly in Indonesia, along with the use of smartphones and the Internet that can be accessed all walks of life in Indonesia. This has an impact on the ease of access to funding loans. The Financial Services Authority (OJK) noted that there were 161 Fintech companies registered in May 2020 with the accumulation of loan distribution of Rp. 109,175,310,000. Fintech has managed to reach various regions in Indonesia because of the ease of data available to make the loan process. It can be accessed remotely through the Internet network. This makes it easier for middle and medium businesspeople to get business capital from Fintech.

Fintech in Indonesia offers a wide range of loan models, one of which is sharia-based Fintech. Indonesia is a country that has the potential of sharia economies because of most of the largest Muslim population in the world. However, the condition does not reflect that the development of Sharia economics positively impacts on the balance of the national economy. Sharia-based Fintech should be able to occupy the highest position in competition with conventional Fintech. Also, Indonesia is the fourth largest country in the world, which is projected to be the largest market for digital trade in southeast Asia. In recent years, Indonesia has also progressed in digitization. Based on such advantages and potentials, it is hoped that all stakeholders should have the focus and effort to address the problems that are becoming a barrier to realizing the potential of the digital economy.

In conducting economic transformation, the Government is strengthening the superior sectors, such as the development of Sharia economics as a source of new economic growth. The development of Sharia economics encourages an inclusive and sustainable economy through increasing the role of sharia enterprises in the halal value chain, as well as the development of Sharia social finance as an alternative source of economic financing, in addition to sharia finance in general. Sharia social finance, when optimized, can encourage the flow of funds to continuously drive the wheels of the economy on an inclusive basis. Efforts to increase the production of the halal industry and sharia economy in general, in time will be expected to increase the demand for financing based on sharia principles. Therefore, it is necessary to innovate Sharia financing products that can be a solution for Sharia business needs.

Currently, Indonesian economic financing instruments that comply with Sharia principles continue to increase, but further acceleration is required to encourage significant growth. Because when viewed from a very broad market share of sharia financing, there is an indication of the gap between Sharia business needs and source of sharia financing. Based on research conducted by Irma Muzdalifah, et al (2018) regarding the role of fintech in improving financial inclusion in MSMEs in Indonesia, fintech for MSMEs can provide Capital Loan services with a simpler process, Digital Payment Services that make the payment process easy and safe, Financial Management Services with the existence of financial regulatory service innovations that aim to assist MSME businessmen in managing their business finances. These services include recording expenses, monitoring investment performance, and financial consulting free of charge. 


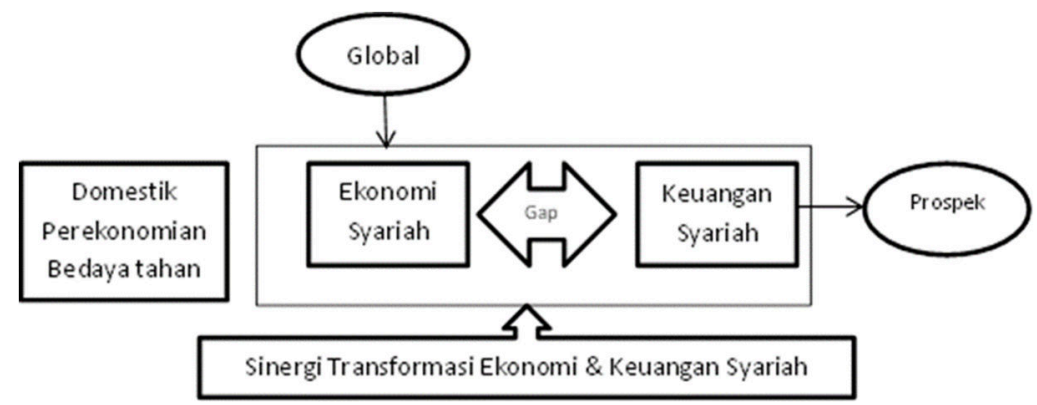

Fig 1. Sharia financing is not optimal (Sharia finance and Economic report, the year 2019, $\mathrm{BI})$

This study aims to look at the causes of this gap, and a solution in the form of bridging sharia businesses utilizing sources of financing through digital media in the form of sharia fintech. It is hoped that the results of this research can be implemented by sharia business actors in developing their business and obtaining long-term benefits so as to generate a sharia economy.

\subsection{Sharia financial institutions}

Sharia financial institution is a business entity whose activities in the field of finance based on sharia principles (Laksmana, 2009:10) or in other words sourced from the verses Al Quran and As-Sunnah relating to the ethics and economic transactions, both in the form of banks and nonbank. The Organization of the Islamic Conference (OIC) in Benghazi, Libya in March 1973 established an Islamic Development bank or Islamic Development Bank (IDB) with an initial capital of 2 billion Islamic dinars (Antonio, 2000:20). In 1992, Indonesia began to establish an Islamic bank named Bank Muamalat Indonesia (BMI). The type of Sharia financial institution in Indonesia under the provisions of the legislation is divided into two, namely, financial institutions of banks and nonbank financial institutions (Hidayat, 2009:17). Islamic financial institutions have principles, among others the principle of justice, the principle of equality, the principle of tranquility, the principle of transparency, and the universal principle. The existence of financial institutions is indispensable to the current economy, because not only as a place to save money but serves as a distribution of funds to the community.

The economic growth and development of Sharia in the financial sector are very encouraging. However, still unfortunate, the growth of the financial sector is so rapid and fast, not balanced with the growth in the real sector of Sharia. Even the development of Sharia real sectors far behind when compared to the financial sector. The two sectors of the economy have to walk balanced (equilibrium). The phenomenon of imbalance is very prone to cause a slowdown in economic growth. Therefore, the development of the financial sector must be balanced with the real sector. To allow the development of the financial sector to move rapidly without being accompanied by the development of the real equilibrium sector become not only a threat of economic destruction, but also violate the principle of Sharia's most fundamental economy, which must associate the monetary sector (financially) with the real sector. 


\subsection{Financial Technology (Fintech)}

One of the technological developments in finance is Fintech. Fintech is one of the innovations in the financial sector that refers to modern technology (Chrismastianto, 2017). Fintech is an innovation in the field of financial services where the physical function of money is not needed anymore but is converted to digital to be more efficient. Fintech has a broad meaning and sense. A research institute, The National Digital Research Centre (NDRC) mentions that Fintech is a term for innovation in financial services, where technology is key. According to the former governor of Bank Indonesia (BI), Agus DW Martowardojo in his keynote speech at the Indonesian Fintech Festival and Conference 2016, in Jakarta said that Fintech is a financial service based on information technology such as big data, cloud computing, and distributed ledger system. While Douglas W Arner, 2015 mentions "Financial technology" or "Fintech" refers to technology-enabled Financial solutions. Fintech refers to a technology that provides a finance solution.

Based on Dorf Leitner, Hornuf, Schmitt, \& Weber (2017), Fintech is a very fast and dynamic moving industry where there are many different business models. According to Ansori, M (2019), Fintech is a service that provides products of financial products using and utilizing information technology that is developing. The existence of a growing Fintech that emerged Shariah-based Fintech and facilitates customers will certainly affect the formal sharia financial industry such as Sharia Bank, BPR Syariah, BMT and other formal sharia financial industry where transactions in the formal sharia financial industry still use physical evidence in its transactions and not much use the growing technological advances. Fintech can also be defined as a digital technology application which aims as financial intermediation (Aaron et al., 2017).

Financial technology According to Bank Indonesia Regulation number 19/12/PBI/2017 is the use of financial system technology that produces new products, services, technology, and business models and can impact monetary stability, financial system stability, efficiency, smooth, security and reliability of payment systems. The organizers of financial technology include payment systems, market supporters, investment management and risk management, loans, financing and capital providers, and other financial services. According to National Sharia Council of MUI No. 117/DSN-MUI/II/2018, Sharia Fintech is the implementation of financial services based on Shariah principles that bring together or connect the financing provider with the financing recipient in order to conduct financing through the electronic system by using Internet network.

\subsection{Micro and Small Enterprises (MSES)}

Micro and Small enterprises (MSES) can be seen from a variety of perspectives (points of view), among others, the ability of capital, industrial sector, managerial skills, institutional, and so on. However, when it refers to the opinion of Primiana that the weakness of MSES in Indonesia is caused by the MSES "not bankable". The important role of MSES institutions on the economy can be seen from the magnitude of the contribution of MSES to the number of business units is necessary to do the following steps; First, the existence of a partnership program for business that has not been bankable, linkage program with microfinance institutions for the expansion of sharia financing, a model of cash collateral guarantee from the agency and financing increase based on the principle of the outcome. This is considering that the MSES sector usually has no collateral. Linkage program is the most major strategy due to the condition of MSES (small-scale, limited collateral, not legal, far-reaching, and weak administration) is very difficult to reach by sharia banks (high cost, high risk, legal requirements, difficult to reach and difficulty assessing efforts). 
Therefore, there is a need for an institution that is a mediator between the MSES and Sharia bank. One very precise institution is BMT. This is because the characteristics of BMT match the needs of MSES, BMT as an extension of the hand of Sharia banks should be able to distribute financing that has been entrusted to him so that sharia banks themselves do not have to fear the enormous risk. Secondly, in terms of management, MSES also needs a companion in this role as a coach to increase capacity building by providing technical assistance in the form of mentoring management, standardized operational procedures (SOP), the use of Information Technology (IT) systems, and marketing products. The absence of business mentoring will result in financing distributed to MSES less precise.

Therefore, sharia banking needs to provide counselling/mentoring related to the above so that the market can absorb the products produced by MSES. Also, appropriate technology is required to meet the requirements of the quality and quantity of products of the MSES desired market. Thirdly, since sharia banks and other financial institutions are faced with the popularity constraints that are still lacking among the community, it is important to improve its popularity to customers, through promotion, advocacy, and various socialization channels in various educational institutions, in cooperation with college colleges, Islamic scholars and organizations.

\section{Research Method}

The research is conducted using two methods, including the quantitative descriptive method by conducting questionnaire dissemination to the 40 MSES as a primer data and using the qualitative descriptive method by conducting a thorough interview of the analyst platform system to the founders. The object of this research is sharia Fintech which conducts sharia financing. Data sources obtained by researchers are primary data, obtained from the results of the analysis of questionnaire data and secondary data obtained from several research studies in scientific papers. The theory used relates to Sharia marketing strategies through the digital economy. The data collection techniques are implemented using the dissemination of questionnaires and conducting interviews with research objects.

\section{Results and Discussion}

The development of sharia finance sector in the year 2019 has not optimally met the needs for business growth, although it has remained growing. The Momentum of the economic recovery from Pandemic COVID-19 impacts will continue to be utilized to encourage the development of Sharia economics. The role of Indonesia's sharia economy as a new source of economic growth is backed by the great potential of global Muslim community consumption, and the fulfilment of domestic needs in various sectors of the halal industry. Efforts to increase the production of the halal industry, as well as sharia economics in general, are expected to increase the demand for financing by sharia principles.

Thomson Reuters and Dinar Standard (2018) Calculate the digital Islamic economy based on e-commerce transactions and digital advertising expenditure conducted by Muslims. The definition of digital Islam economy as part of the Islamic economy that supports the halal industry through a good digital platform that can increase sales and 
production efficiency that will eventually increase the company's performance (MasterPlan Ekkeu Syariah 2019-2024).

The growth of the digital economy can be seen through the growth of two subsectors, namely e-commerce and Fintech. Based on the Indonesian Sharia Fintech Association page (AFSI) on November 2018, 37 members joined AFSI since the establishment of October 2017. AFSI members not only consist of sharia fintech, but also include institutions, academics, and associations that have activities related to sharia fintech. So far, the distribution of sharia fintech in Indonesia is still dominated by the lending business sector, both P2P lending/investment and consumer credit. From 37 AFSI members, at least 31 of which are sharia fintech companies, the lending sector amounted to 23 companies, crowdfunding three companies, personal finance and wealth management amounting to 3 companies, accounting for one company, and Point-of-sale amounting to 1 company.

At the same time, other institutions are academic institutions, consultants, and the marketplace. They see the growth of digital transactions through mobile applications, the launch of potential mobile applications to increase sharia fintech growth. According to processed data from Google Play Store, until November 2018, there are 15 Sharia fintech have a mobile app on the Android platform.

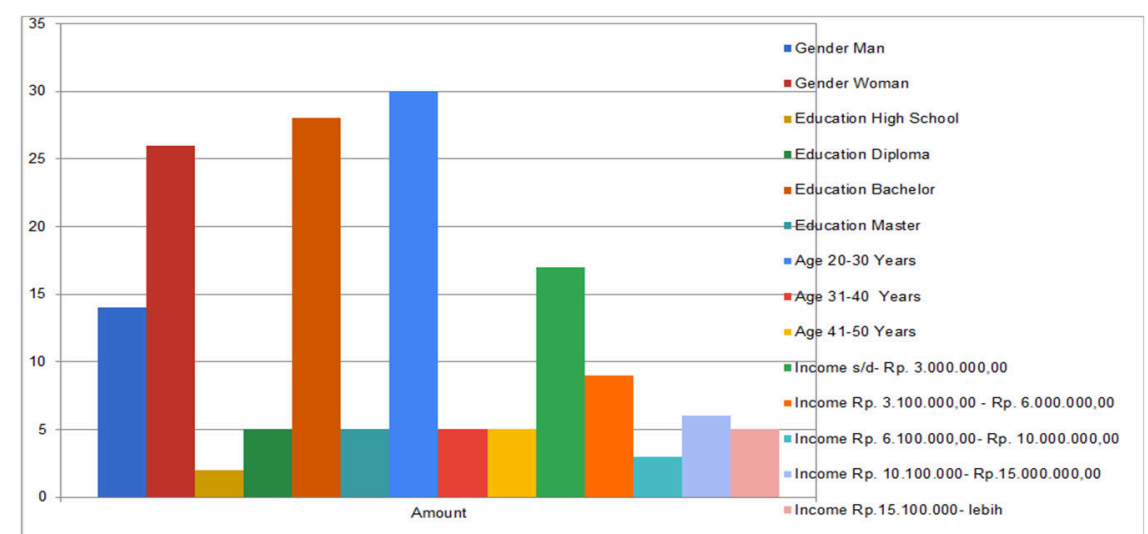

Fig 2. Respondent's identity (Data Processing Results 2020)

In table 1 shows that the results of data processing and discussion in this study were obtained from the dissemination of questionnaires to 40 MSES that became primary data. The results of the descriptive analysis showed that respondents aged 20 years to 30 years as many as 30 respondents $(75 \%), 31$ to 40 years as many as five respondents $(12.5 \%)$, and 41 to 50 as many as five respondents $(12.5 \%)$. Female Gender is 26 respondents $(65 \%)$, while males are 14 respondents $(35 \%)$. The last education of Senior High School was two respondents $(5 \%)$, a Diploma of 5 respondents $(12.5 \%)$, a bachelor's degree of 28 respondents (70\%), and a Master of 5 respondents (12.5\%). Revenue up to Rp. 3,000,000.00 as many as 17 respondents $(42.5 \%)$, Rp. 3,100,000.00-Rp. 6,000,000.00 as many as 9 respondents $(22.5 \%)$, Rp. 6,100,000.00-Rp. 10,000,000.00 as many as 3 respondents (7.5\%), and Rp. 10,100,000.00-Rp. 15,000,000.00 as many as 6 respondents $(15 \%)$, and above Rp. 15,000,000.00 as many as 5 respondents (12.5\%). This questionnaire consists of 30 questions outlined according to several variables to be researched, among them: the relationship between the level of FINTECH (X1), Quality System (X2), Features of Service (X3), and Wishes to use SHARIA FINTECH (X4) in MSES Performance (Y). 
Table 2. Analysis of Correlation Variables

\begin{tabular}{lccc}
\hline \multicolumn{1}{c}{ Variables } & $\begin{array}{c}\text { The range of } \\
\text { value (r count) }\end{array}$ & Requirement & Des \\
\hline Level of understanding FINTECH $\left(\mathrm{X}_{1}\right)$ & $0,506-0,885$ & 0,312 & Valid \\
\hline Quality System $\left(\mathrm{X}_{2}\right)$ & $0,931-0,964$ & 0,312 & Valid \\
\hline Features of service (X3) & $0,739-0,931$ & 0,312 & Valid \\
\hline $\begin{array}{l}\text { Wishes to use SHARIA FINTECH } \\
\text { (X4) }\end{array}$ & $0,723-0,928$ & 0,312 & Valid \\
\hline MSES Performance (Y) & $0.320-0.838$ & 0,312 & Valid \\
\hline
\end{tabular}

Based on table 2 can be seen that with a significant rate of $5 \%, 40$ respondents acquired $\mathrm{R}$ table 0.312 . In such tables, the validity test for the $\mathrm{X} 1$ variable that is the Level of Understanding FINTECH (X1) indicates that all query items have a value of $\mathrm{R}$ Count greater than 0.312 , which means it is valid or feasible to be used for research. The validity test for the variable X2 which is the Quality System indicates all query items have a value of R Count $0.931-0.964$ greater than 0.312 , which means it is valid or feasible to be used for research. For a variable X3 which is the Features of service shows all the query items have a value of $\mathrm{R}$ Count 0.739-0.931 meaning valid, as well as X4 the Wishes to use SHARIA FINTECH shows all query items have a value of R Count 0.723-0.928 meaning valid.

\subsection{Variable 1}

R X 1.1 with X $1.5=0.502$ shows significant positive meaning information technology as a means to improve the quality of service for users also facilitate me in interacting with the existence of Sharia Fintech. R X 1.1 with X $1.7=0362$ shows significant positive meaning information technology as a means to improve the quality of service for users also interested in the existence of Sharia FINTECH as an innovation of the financial industry. R $\mathrm{X} 1.1$ with $\mathrm{X} 1.8=0521$ shows significant positive meaning information technology as a means to improve service quality for users also interested in the existence of intermediation institutions (Shopee, Tokopedia, Bukalapak, etc.) to connect financial services. R X 1.1 with $\mathrm{X} 1.9=0500$ shows significant positive meaning information technology as a means to improve the quality of service for users also easier to access financial institutions services through intermediation agencies (Shopee, Tokopedia, Bukalapak, and others). R X 1.1 with $\mathrm{X} 1.10=0511$ shows significant positive meaning information technology as a means to improve the quality of service for users also will use financial institution services through intermediation institutions (Shopee, Tokopedia, Bukalapak, and others).

\subsection{Variable 2}

R X 2.1 with X $2.2=0863$ shows significant positive meaning that the SHARIA FINTECH ensures the security of the information provided by the SHARIA FINTECH system has the capability to implement and fulfil the promised service. R X 2.1 with X 2.3 $=0881$ shows significant positive meaning that the SHARIA FINTECH ensures the security of the information provided by the system as well as SHARIA FINTECH has a system response speed to the actions performed by the user (System responsiveness). R X 2.1 with X $2.4=0843$ shows a significant positive meaning that existing SHARIA FINTECH 
guarantees the security of information provided by the system as well as SHARIA FINTECH has fulfilled the necessary needs. R X 2.2 with X $2.3=0889$ shows significant positive meaning that the SHARIA FINTECH can implement and fulfil the promised services, as well as SHARIA FINTECH, has a system response speed to the actions performed by the user (System responsiveness). R X 2.2 with X $2.4=0782$ shows significant positive meaning that the SHARIA FINTECH has the capability to implement and fulfil the promised services, as well as SHARIA FINTECH, has fulfilled the necessary needs.

\subsection{Variable 3}

R X 3.1 with X $3.2=0783$ shows a significant positive meaning that the MSES players will use the savings service through the SHARIA FINTECH will also use Sharia lending services through SHARIA FINTECH. R X 3.1 with X $3.3=0489$ shows significant positive meaning that the MSES will use the savings service through the SHARIA FINTECH will also use the payment services Zakat, Infaq and Shodaqoh through SHARIA FINTECH. R X 3.1 with X $3.4=0749$ shows significant positive means that the MSES will use the savings service through SHARIA FINTECH will also use the services of cooperatives through SHARIA FINTECH. R X 3.1 with X $3.5=0857$ shows significant positive meaning that the MSES players will use the deposit service through the SHARIA FINTECH will also use the payment service through SHARIA FINTECH. R X 3.1 with X 3.6 = 0693 shows significant positive meaning that the MSES players will use the savings service through the SHARIA FINTECH will also use crowdfunding services (mutual funding for specific purposes, e.g. Infaq, zakat, etc.) through SHARIA FINTECH. R X 3.1 with X $3.7=0747$ shows significant positive meaning that the MSES will use the deposit service through the SHARIA FINTECH will also use the Payment Gateway Service (payments connecting customers and sellers such as Shopeepay, Dana, Ovo) through SHARIA FINTECH. R X 3.1 with X $3.8=0781$ shows significant positive meaning that the MSES will use the deposit service through SHARIA FINTECH also use FINTECH PAYMENT SYARIAH will provide benefits in business.

\subsection{Variable 4}

R X 4.1 with X $4.2=0486$ shows significant positive meaning the MSES actors are keen to use SHARIA FINTECH products because more practical use of FINTECH PAYMENT SYARIAH increases prestige/prestige of the MSES. R X 4.1 with X $4.3=0624$ shows significant positive meaning MSES is interested in using SHARIAH FINTECH products because more practical also SHARIA FINTECH services can be accessed through mobile phone by downloading in Playstore/AppStore. R X 4.1 with X $4.4=0768$ shows significant positive meaning the MSES actors are keen to use SHARIA FINTECH products because more practical also SHARIA FINTECH services faster than other transaction methods (time). R X 4.1 with X $4.5=0845$ shows significant positive meaning the MSES actors are keen to use SHARIA FINTECH products because more practical use of SHARIA FINTECH increases MSES revenue.

\subsection{Reliability Test}

The reliability test in the study was done by looking at the Value of Cronbach Alpha. An instrument is said to be reliable when the alpha coefficient has a value greater than 0.60 . The results of the reliability of all variables in this study can be seen that the level of understanding of FINTECH (X1), quality System (X2), service features (X3), the desire to 
use Sharia FINTECH (X4) and MSES Performance (Y) has a coefficient value greater than 0.60 with a value of each 0.888 for an (X1), 0.956 for (X2), 0.951 for (X3), 0.886 for (X4) and $0615(\mathrm{Y})$. This indicates that the question items within each variable can be said to be reliable for measuring variables. From the results of the Analysis of Correlation Variables and the reliability test results variables that the level of understanding FINTECH (X1), quality System (X2), service features (X3), the desire to use Sharia FINTECH (X4) has a significant effect on the MSES Performance (Y). It is very supportive of Sharia FINTECH development. One of the advantages of Sharia Fintech is the uncomplicated process and can be submitted through the application in the mobile phone-each of the private individuals of MSES actors. Based on the list of OJK, the last data showed already 7 Shariah-labeled Fintech companies, which sell sharia loans.

First, Investee a Shariah Fintech that has Value Added in the form of services that can be utilized by anyone who has fulfilled the terms and conditions as Borrower and lenders Investee, both Muslim and non-Muslim. The strategy that is applied to the products owned by Fintech Syariah is the halal flagship product. Besides, it has an advantage in the disbursement procedure with a time of 1-2 auspicious days for MSES. Secondly, Amana in cooperation with Takaful Company, Askrindo Syariah and Jamkrindo Syariah become underwriting companies to reduce risk to financing. The Ammana Platform applies the profit-sharing of productive funding results with a pure system for the outcome of lenders with Sharia microfinance institutions Ammana partners such as BMT, KSPPS, BPRS, Sharia venture institutions, and other sharia financial institutions. The promotion mix provided by Ammana to attract the MSES as much as possible is to conduct promotions through social media such as Facebook, Instagram, YouTube.

Third, Danaku Syariah. Multi-purpose loans are aimed at financing the purchase of goods, vehicles or home payments with a murabahah contract. The Nominal financing is $\mathrm{Rp}$ 1 to Rp 10 million, -with a tenor of 3, 6, 9, and 12 months. The multi-service loan is a private loan without RIBA that is aimed at financing public use with Akad Wakalah bil Ujrah. The amount of financing and its number is the same as multi-use loans. Danaku Syariah provides a more competitive and lightening result for MSES. Fourth, Syariah fund has sharia MORTGAGE products. Syariah Fund builds Shariah-based e-commerce called Halalpedia to attract people who love to shop online and want the process to be by Islamic law. The yield is equivalent to $20 \%$ per year with a halal, safe and easy principle.

Fifth, Syariah Dhuha. Syariah Dhuha offers two types of loan products, among others, the consumptive purchase of goods and services as well as religious travel. Dhuha Syariah in cooperation with the marketplace such as Duniahalal.com and Bhinneka.com who can make goods/services orders in another marketplace by contacting Customer Service through WhatsApp media. Sixth, ALAMI Sharia. ALAMI Sharia brings together the MSES with financing lenders. This type of financing is invoice financing from Rp 50 million to $\mathrm{Rp} 2$ billion. It will fund a maximum of $80 \%$ of the invoice value you have. The process by creating an account for three minutes. For approved financing recipients through the ALAMI Risk assessment criteria assessment.

Seventh, Syarfi. Syarfi connects the owners of funds from various countries with the Indonesian people who need funds. The requirement of funding for financing in the form of service and business financing in Indonesia for individuals or business companies. Syarfi is one of the registered legal Fintech that is supervised by OJK in offering Sharia-based loan products, with crowdfunding funding. The loan products are offered complete ranging from education, health, business capital, marriage, circumcision and property. Syarfi has four loan products, such as financing buying and selling goods (Murabahah), Financing Services 
(Ijarah), social financing (QARDH) and business Financing (Musyarakah). The ceiling is offered to range from 2 million to 2 billion rupiahs, a period of 1-12 months with an ujrah which is imposed from $3-6 \%$.

Laku Habis develop productive business and investment in improving the quality of MSES activities by encouraging saving and supporting financing activities. In addition to providing financing facilities with sharia principles to MSES who require working capital to expand the business. Laku Habis also provide counselling or business assistance to the MSES to help the MSES can survive under any circumstances. Laku Habis also facilitates gathering funds from third parties (depositors) to provide MSES financing to a productive and profitable business.

\section{Conclusion}

Sharia fintech market opportunities are still wide open, seen from the sharia economic side that continues to experience significant growth. One of the advantages of Sharia fintech is the process that is not difficult and can be submitted through applications in the personal mobile phone of MSES. Based on the data in the OJK list, shows eight Fintech companies based on sharia principles. Products offered include gathering funds and sharia financing. Reviewed from the needs of the MSES players, Fintech is the closest is Laku Habis.

Laku Habis develop productive business and investment in improving the quality of MSES activities by encouraging saving and supporting financing activities. In addition to providing financing facilities with sharia principles to MSES who require working capital to expand the business. Laku Habis also provide counselling or business assistance to the MSES to help the MSES can survive under any circumstances. Laku Habis also facilitates gathering funds from third parties (depositors) so as to provide MSES financing to a productive and profitable business.

\section{References}

[1] Aaron, M., Rivadeneyra, F., \& Sohal, S. (2017). Fintech: Is This Time Different? A Framework for Assessing Risks and Opportunities for Central Banks. Bank of Canada. Retrieved from www. Bank - Banque Canada.

[2] Ansori M, 2019. The development and impact of Financial Technology (Fintech) on sharia finance industry in Central Java. Journal of Keislaman Vol. 5 No. 1: Rides Islamika

[3] Antonio, S., 2000. Sharia Bank from theory to practice. Jakarta: Gema Insani.

[4] Arnes, Douglas W. Et Al. 2015. The Evolution of Fintech: A New Post-Crisis paradigm. Journal of International Law Research Paper No. 2015/047: University of Hong Kong

[5] Chrismastianto, I. (2017). SWOT Analysis of financial technology implementation of the quality of banking services in Indonesia. Journal of Economics and Business, 20 (1), 133-144.

[6] Dorfleitner, Hornuf, Schmitt, \& Weber. (2017). Retrieved March Sunday, 2019, from CourseHero: https://www.coursehero.com/

[7] Hidayat, A. (2009). Recognizing the Islamic economic system. Yogyakarta: Pustaka Insan Madani.

[8] MasterPlan Sharia Financial Economics 2019-2024

[9] Money and Bank, Bina Aksara, Jakarta, 1987, p. 111, quoted in Neni Sri Imaniyati, Introduction to Indonesian banking law, Refika Ditama, Bandung 2010, p. 2.

[10] Muzdalifah, Irma. Et Al. (2018). Fintech's Role in Improving Inclusive Finance in MSMEs in Indonesia. Journal of Islamic Economics and Banking, Vol. 3, No. 1, Muhammadiyah University surabaya. 
[11] Laksmana, Y. (2009). Bank Sariah's Account Officer understands the financing process practices in Sharia banks. Jakarta: PT Gramedia

[12] Regulation of the Financial Services Authority No. 55/POJK. 04/2015. The establishment and guidelines for implementing the Audit Committee. (Online) www.ojk.go.id/regulasi/peraturanojk/POJK-Nomor55.POJK.04.2015/.

[13] Ministry of Finance Decree No. 792 the year 1990.

[14] Thomson Reuters \& Dinar Standard. (2018). State of the Global Islamic Economy Report 2018/19. Dubai.

[15] Bank Indonesia Regulation Number 19/12/PBI/2017 On the Implementation of Financial Technology.

[16] National Sharia Board of MUI No. 117/DSN-MUI/II/2018 concerning information technology-based financing services based on sharia principles. 